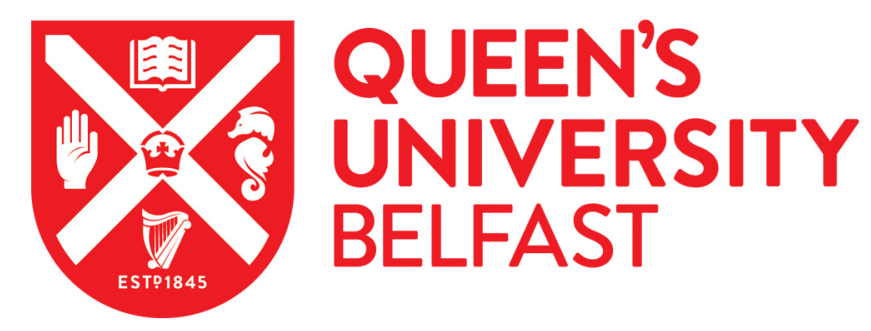

\title{
A cultural selection analysis of human-dog interactions - a primer
}

Pfaller-Sadovsky, N., \& Hurtado-Parrado PhD, C. (2020). A cultural selection analysis of human-dog interactions - a primer. European Journal of Behavior Analysis.

https://doi.org/10.1080/15021149.2020.1791682?journalCode=rejo20

\section{Published in:}

European Journal of Behavior Analysis

\section{Document Version:}

Peer reviewed version

\section{Queen's University Belfast - Research Portal:}

Link to publication record in Queen's University Belfast Research Portal

\section{Publisher rights}

(C) 2020 Informa Limited, trading as Taylor \& Francis.

This work is made available online in accordance with the publisher's policies. Please refer to any applicable terms of use of the publisher.

\section{General rights}

Copyright for the publications made accessible via the Queen's University Belfast Research Portal is retained by the author(s) and / or other copyright owners and it is a condition of accessing these publications that users recognise and abide by the legal requirements associated with these rights.

Take down policy

The Research Portal is Queen's institutional repository that provides access to Queen's research output. Every effort has been made to ensure that content in the Research Portal does not infringe any person's rights, or applicable UK laws. If you discover content in the Research Portal that you believe breaches copyright or violates any law, please contact openaccess@qub.ac.uk. 
See discussions, stats, and author profiles for this publication at: https://www.researchgate.net/publication/ 342655770

\section{A cultural selection analysis of human-dog interactions - a primer}

Article in European Journal of Behavior Analysis · July 2020

DOI: $10.1080 / 15021149.2020 .1791682$

\section{CITATIONS}

0

2 authors:

No. Nicole Maria Pfaller-Sadovsky

Queen's University Belfast

4 PUBLICATIONS 4 CITATIONS

SEE PROFILE
1

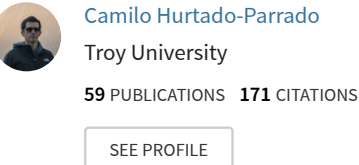

Some of the authors of this publication are also working on these related projects:

Effects of goal clarification on impulsivity and academic procrastination of college students View project

Special issue Frontiers in Psychology/Education: Research on Emotion and Learning: Contributions from Latin America View project 


\section{A Cultural Selection Analysis of Human-Dog Interactions - A Primer}

Nicole Pfaller-Sadovsky ${ }^{\mathrm{a}^{*}}$ and Camilo Hurtado-Parrado ${ }^{\mathrm{b}, \mathrm{c}}$

${ }^{a}$ School of Biological Sciences, Queen's University Belfast, United Kingdom; ${ }^{b}$ Department

of Psychology, Troy University, United States of America; ${ }^{c}$ Faculty of Psychology,

Fundación Universitaria Konrad Lorenz, Colombia

*Corresponding author Nicole Pfaller-Sadovsky

Neunkirchnerstrasse 120, A-2724 Puchberg/Schneeberg, Austria

Telephone +436644226538

E-mail: npfaller01@qub.ac.uk 


\section{A Cultural Selection Analysis of Human-Dog Interactions - A Primer}

Mounting interest in the evolutionary and contemporary aspects of human-dog association has resulted in growing research efforts from different disciplines with differing methodologies and areas of emphasis. Despite its potential to contribute to the understanding of human-dog interactions, behavior-analytic research efforts are scarce. We are illustrating how the behavior-analytic three-level selection by consequences framework could be applied to inform research on human-dog interactions. Therefore, the notions of interlocking behavioral contingencies and metacontingencies are applied to interpret specific interactions and suggest potential lines of research. We first analyze the development of cooperative hunting of prehistoric humans and dogs, and its implications for interspecific social-communicative skills. Second, we discuss contemporary family practices that involve the interactions between parents, children and family dogs via an analysis of a prototypic social episode. Lastly, we provide an overview of the main approaches that have contributed to the understanding of the human-dog interactions (e.g., anthrozoological), and show how their findings can be placed within the behavior-analytic framework. We conclude that the coherence of the selectionist framework is a major strength that not only can contribute to synthesize a large amount of scattered research on human-dog relationships conducted across various fields, but can also inform further research and applications. 202 words

Keywords: three-level selection, metacontingency, interlocking behavioral contingency, human-dog interactions 


\section{Introduction}

Dogs (Canis lupus familiaris) are often called "man's best friends." This is not surprising given the millennia-long cohabitation of humans and dogs. Archaeological evidence from prehistoric sites across the globe indicates that dogs were the first domesticated animals, and humans and dogs hunted cooperatively for at least 8,000 years (Clutton-Brock, 2017; Grimm, 2017; Savolainen et al., 2002). Although a history of cooperative hunting is well supported by different studies (Koler-Matznick, 2002; Lescureux, 2018; Lupo, 2017; Perri, 2016; Shipman, 2014; Yeomans et al., 2019), the actual process of domestication and history of global dispersal of dogs continues to be contentious (Larson et al., 2012; Leathlobhair et al., 2018). For instance, an early genetic study concluded that dogs were domesticated 135,000 years ago at multiple sites across Eurasia (Vila et al., 1997), while a later study reported that domestication was initiated in East Asia during a single event approximately 15,000 to 40,000 years B.P. (Savolainen et al., 2002). In any case, prior to becoming man's best friend, in early days dogs seem to have been critical for human hunting success and survival on almost all continents (Guagnin et al., 2018; Leathlobhair et al., 2018; Perri, 2016). Although some societies perceive dogs as vermin or keep them for human consumption (Coppinger \& Coppinger, 2016; Germonpre et al., 2017; White, 2018; Tanabe, 2006), the overall amicable and prosperous association of humans and dogs persisted over millennia into various contemporary societies (Jervis et al., 2018).

The mounting interest in the evolutionary and contemporary aspects of human-dog association has resulted in rapidly growing research efforts from a wide range of disciplines with dissimilar assumptions, methodologies, and areas of emphasis; among them, anthrozoology, behavioral ecology, comparative cognition, ethology, genetics, neuroscience, psychology, social sciences, and veterinary behavior and medicine (e.g., Bennett, 2013; Carlisle et al., 2018; Fall et al., 2019; Fukuzawa \& Hashi, 2017; Gray et al., 2015; Jervis et al., 2018; Ortolani et al., 2009; Persson et al., 2018; Rehn \& Keeling, 2016; Seksel \& Lindeman, 2001; Taylor et al., 2016; van der Borg et al., 2018; van Herwijnen et al., 2018; Yamamoto et al., 2009; Yilmaz, 2017). Despite the popularity of canine-related research among various disciplines, behavior analytic research efforts are scarce (e.g., Edwards \& Poling, 2011; Feuerbacher \& Wynne, 2015; Feuerbacher \& Wynne, 2016; Hall, 2017; Hall et al., 2015; Pfaller-Sadovsky et al., 2017; Protopopova et al., 2016), notwithstanding their 
potential to contribute to the understanding of the behavioral phenomena entailed in humandog interactions, and application when needed.

Our aim here is twofold: First, to propose how the behavior analytic three-level selection by consequences framework - biological, behavioral, and cultural - could be applied to understand different forms of human-dog interactions across those three levels. We will illustrate the relevance of the framework by applying it to some specific interactions (e.g., cooperation of Paleolithic humans and canines during hunting episodes and contemporary family interactions with dogs) and suggesting potential courses of research. Second, to propose a taxonomy that synthesizes the different approaches that have contributed to the understanding of the human-dog interactions in terms of two models: namely, anthrozoological and comparative cognition. For each we will provide an overview and key findings. We expect that this primer will help researchers unfamiliar with the field, including experimental and applied behavior analysts, to approach the major findings and theoretical discourses that emerge across the diverse information currently available. To our knowledge this is the first time that such theoretical account is attempted. Overall, we argue that the coherence of the behavior analytic approach is a major strength that, when compared to other approaches, could help systematize a great amount of the scattered knowledge about humandog interactions currently available, and more importantly, inform further research and applications.

\section{Human-dog relationships: How can Behavior Analysis contribute?}

While different disciplines have provided important hints and evidence about how human-dog relationships evolved and are currently maintained (e.g., Cimarelli et al., 2017), behavioranalytic contributions to these areas of inquiry are scarce (e.g., Feuerbacher \& Wynne, 2016). Here, we will introduce the behavior analytic three-level of selection by consequences framework - biological, behavioral, and cultural - and then we will illustrate how it could be used to understand different aspects of the human-dog interactions, not only by integrating the findings that other approaches have contributed, but also by providing potential courses of research and application. As Skinner (1987) indicated, though initial research efforts often allow us to interpret only current practices, we expect that the selection-by-consequences framework will ultimately guide experimental and applied research aimed at reaching "prediction and control" (p. 11) of relevant facts. 
Three levels of selection by consequences: Biological, behavioral, cultural

From a behavior analytic perspective, selection by consequences is the operating principle for biological, behavioral, and cultural phenomena (Skinner, 1981; Skinner, 1987). It is understood as a general form of causation that differs from the push-pull mechanistic Newtonian model of physics and operates at the three levels of phylogeny, ontogeny, and culture (Catania, 2013; Hull, Langman, \& Glenn, 2001).

\section{Biological selection}

In the first level (phylogeny), selection by consequences involves the processes of differential reproduction (i.e., natural selection) and changes in the genetic make-up of the species (i.e., selection in biological evolution; Hull et al., 2001). These processes entail contingencies of survival or phylogenic contingencies (Skinner, 1984); the ecological environment has requirements for the reproduction of the members of a species, which may remain stable for long periods of time or may change gradually or suddenly. Those individuals who exhibit features, including behavior, that are appropriate for those contingencies, then survive long enough to reproduce (Pierce \& Cheney, 2017).

\section{Behavioral selection}

The second level of selection accounts for the shaping and maintenance of the behavior of the individual-i.e., ontogenetic - and entails operant contingencies (reinforcement and punishment). Skinner (1981) proposed that operant conditioning must have evolved in parallel with two other traits; namely, susceptibility to reinforcement by certain kinds of consequences, and variation in the degree to which behavior is uniquely controlled by evoking stimuli. Organisms that inherited a disposition to operant conditioning improved their adjustment to complex and changing situations. Adaptation to complex social environments, including verbal behavior (behavior that operates on another individual, who mediates reinforcement of the verbal performance; Skinner, 1957) seemed to have been a special case of this process (Glenn, 2004; Hull et al., 2001).

\section{Cultural selection}

A third level of selection applies to cultures (i.e., cultural selection), which could be understood as "patterns of learned behavior transmitted socially, as well as the products of that behavior (objects, technologies, organizations, etc.)" (Glenn, 2004, p. 139). Cultural 
selection entails how large-scale consequences select variations of the cultural practices of a group in terms of their efficiency, costs, or survival (Skinner, 1981). Considering the different usages (often vague) of the term cultural practice across disciplines, in the present context they should be understood as recurring, similar, observable patterns of behavior displayed by groups of individuals (behaving individually or in relation to others) that have consequences in the environment (Glenn, 2004).

The analysis of cultural practices from a functional perspective entails the notion of interlocking behavioral contingencies (IBCs), in which two or more individuals provide discriminative and reinforcing stimuli for each other (Glenn, 1988; 2004); e.g., to free a car stuck in the snow, the driver accelerates and steers, while two more individuals push from behind the vehicle (Pierce \& Cheney, 2017). This approach considers group-level practices as functionally similar to operants at the individual level, in that both are selected by consequences. However, metacontingencies apply to the case of cultural practices (see conceptual discussions; e.g., Delgado, 2012; Mattaini, 2006). Metacontingencies thus refer to interdependent relations between practices that involve IBCs (e.g., coordinated responses of the individuals interacting among them and with the car stuck in the snow), which result in a product/consequence of those practices for the group (e.g., the car getting out of the snow; Glenn, 1988; 2004). Metacontingencies could be technological or ceremonial. Examples of technological metacontingencies include collaborative efforts (i.e., IBCs) to hunt or plant crops to supply food for a group of individuals. Examples of ceremonial metacontingencies are coordinated responses entailed in holiday festivities, weddings, and birthday parties that result in diverse consequences for the groups of individuals involved in these IBCs (Pear, 2016). As will be discussed later in this paper, dog-human interactions could be understood from a metacontingencies perspective, including an analysis of their technological (e.g., hunting, herding, guarding) or ceremonial (e.g., birthday celebrations, play dates) function.

According to this behavior analytic perspective, human cultures could be understood as sets of practices related to the functioning of different aspects of the society (e.g., mating, child-rearing, religion, and art; Pear, 2016). The evolution of a high disposition to operant conditioning, a strong tendency to spend time in close proximity to other individuals (i.e., sociality; Glenn, 2004), and complex operant control of the vocal musculature (more generally, verbal behavior) seemed to have allowed for the evolution of human cultures (Glenn, 2004; Hull et al., 2001; Skinner, 1981). 


\section{Paleolithic hunter-gatherer societies and domesticated wolves}

The dog is the only animal that was domesticated prior to the origin of agriculture (Germonpre et al., 2018; Kukekova, Trut, \& Acland, 2014). It is widely accepted that the beginnings of domestication took place towards the end of the Pleistocene, when human populations were still living in small hunter-gatherer clans of between 20 to 50 individuals (Groeneveld, 2016) and agriculture was not yet practiced (Thalmann et al., 2013; Morey \& Jeger, 2015). While the Middle Paleolithic period is associated with Neanderthals (Homo neanderthalensis), the Upper Paleolithic (i.e., 45,000 years to about 11,700 years B.P.) is associated with modern humans (Homo sapiens; Germonpre et al., 2018; Pierotti \& Fogg, 2017). Based on genetic evidence from both modern humans and dogs (Druzhkova et al., 2013; Germonpre et al., 2009; Ovodov et al., 2011), it is hypothesized that early humans' migration out of Africa into Paleolithic cold steppe (i.e., today's Eurasia), and their first encounters with wolves are suggested to have happened at approximately the same time, namely, 40,000 years B.P. (Pierotti \& Fogg, 2017). Paleolithic hunter-gatherers and wolves showed remarkable similarities in their lifestyles: (a) both species lived in social groups, (b) they preferred to hunt big game - e.g., mammoth or bison, and (c) they were hunting cooperatively (Jung \& Pörtl, 2018). Archaeological evidence (e.g., bones of wolves have been found in association with those of early hominins) further indicates that the sites of occupation and hunting activities of both species may have overlapped often (Clutton-Brock, 2017). It is thought that early Homo sapiens observed wolf packs hunting big prey, and so learned how to do it better themselves (Jung \& Pörtl, 2018). During their encounters, humans may have repeatedly adopted wolf puppies and allowed the most cooperative individuals to reproduce (Kukekova et al., 2014). After several generations of selection for docile behavior (i.e., artificial selection, which is the selection of benefiting natural variations for human ends; Driscoll, Macdonald, \& O’Brien, 2009), primitive pro-social dogs (i.e., "proto-dogs") may have emerged (Germonpre et al., 2018; Miklosi, 2015). The resulting association between humans and proto-dogs might have contributed to the displacing of other competing hominins (i.e., the Neanderthals; Lupo, 2017; Pierotti \& Fogg, 2017; Shipman, 2015). The adopted interspecific cooperative hunting strategy may have resulted in an improvement in hunting efficacy (Germonpre et al., 2015; Shipman, 2015). It is hypothesized that this newly acquired technology led to a growth in human population size, which may have contributed to the expansion of modern humans (Lupo, 2017; Shipman, 2015). 
Viewing interspecific cooperative hunting as a technological advancement (similar to the development of human-only cooperative hunting strategies, as exemplified by Glenn, 2003), the third level of selection (i.e., cultural selection) may be helpful in understanding the early associations of humans and dogs from a functional point of view. Cooperative hunting between humans and proto-dogs can be viewed as a metacontingency (Figure 1; adapted from Glenn, 2010, p. 82). A metacontingency focuses on the selection of coordinated responses that enable group members to achieve a common goal (Glenn et al., 2016). Metacontingencies, therefore, involve recurring IBCs between two or more organisms that provide discriminative stimuli or reinforcement for each other (Glenn, 1988; 2004). Similar to Glenn's (2010) example of the behavior of a team of players in a ball game (Glenn, 2010, p. 80), cooperative hunting of humans and dogs can also be explained in this regard. For instance, the behaviors of humans and dogs are also spatiotemporally localized to the area where certain prey animals are abundant, and the two cooperating species also function as elements in highly organized IBCs that reoccur during the hunt (e.g., synchronized stalking) and across hunting occasions. The IBCs of cooperative hunting between humans and dogs functioned as a cohesive and integrated unit and could result in an aggregate product, such as increased prey acquisition rate. This aggregate product results in more prey by numbers and/or successfully hunting larger or faster mammals than would be possible by a humansonly hunting party. The critical point here is that the maximization of food resulting from the interrelated behavior among the individuals of the human-dog hunting party functioned as a selection process on all three levels (Glenn, 2003; Hull et al., 2001). First, it contributed to natural selection by improving fitness of involved humans. Second, it supported the cooperative operants of participating organisms. And third, it selected the interlocking contingencies in which the participating individuals engaged in. 


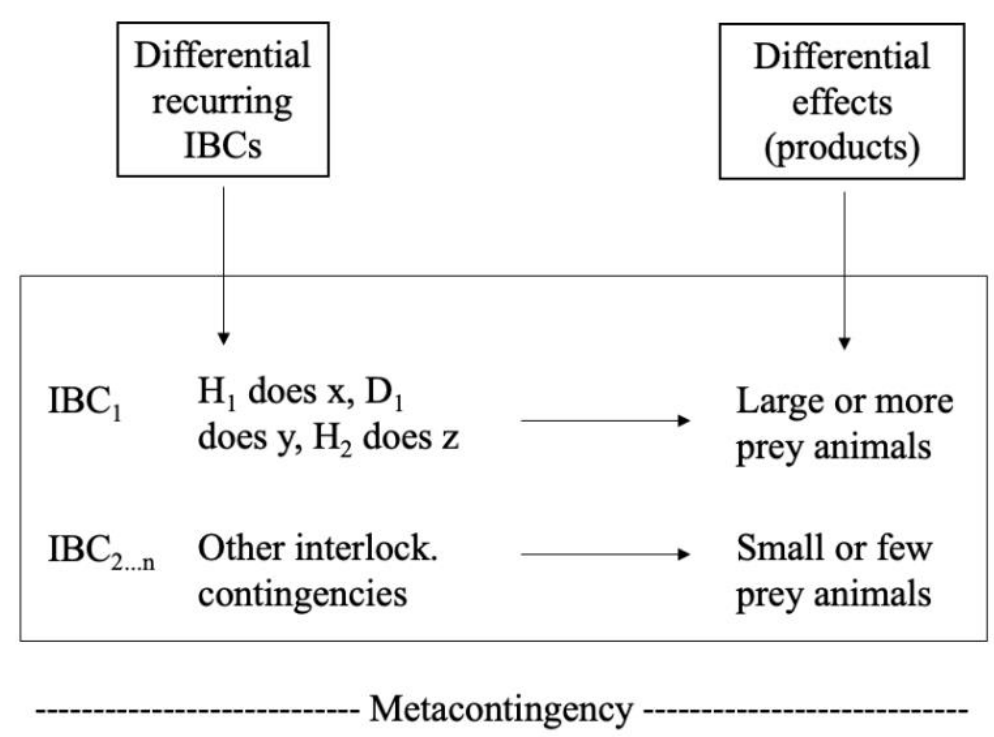

Figure. 1 Schematic display of elements in a metacontingency. While the recurrence of $\mathrm{IBC}_{1}$ and its differential effects ("large or more prey") increase in occurrence, the recurrence of alternative variations of $\mathrm{IBC}_{2} \ldots \mathrm{n}$, with respective products, decrease ("small or few prey animals") relative to $\mathrm{IBC}_{1}$. Note. $\mathrm{H}=$ human, $\mathrm{D}=\operatorname{dog}$ (adapted after Glenn, 2010, p. 82).

Increased prey acquisition rates could also have led to environmental changes external to the IBCs, such as increased human population due to improved nutrition or decreased risks of getting too close to a wounded large prey as the dogs would kill the prey animal. Growing numbers of humans could have "fed back" into the IBCs by providing additional hunters or forming new IBCs with different individuals participating in the IBCs from one occasion to the next (Glenn, 2003). The transmission of technologies, such as interspecific cooperative hunting, involves learning of one organism, through the behaviors of other organisms (i.e., "social learning"; Glenn, 2003; 2004); hence, transmission comprises recurrences of interrelated behavior of two or more organisms, and one organism's behavior functions as the consequence in the operant contingency accounting for the responses of the other (Glenn, 2004). In the transition from operant behavior to cultures, events functioning as reinforcers for individual behavior in IBCs may also function as cultural-level selectors for the interlocking contingencies as cultural-level units. The selection mechanism does not necessarily have to be behavioral selection among individuals within the interlocking contingency; however, IBCs are upheld and outlive the repertoires of any of the participating organisms if they function properly in the cultural selection contingencies (Glenn, 2003). Therefore, when a socially learned behavior is reproduced in the repertoires of other organisms, a new type of "culture" emerges (Glenn et al., 2016). Although cooperative hunting with dogs is a practice that has persisted into current times, it has varied considerably 
across millennia. For example, based on the discovery of gun powder and following technological changes, dogs were also specifically bred for the species of prey animals they were supposed to hunt with their humans (Lord et al., 2017; Menache, 2005; Serpell, 2017), such as retriever breeds that were originally bred to retrieve shot or wounded small game (e.g., grouse and ducks; The Kennel Club, 2019).

Behavior within IBCs is maintained by reinforcement contingencies among organisms; however, IBCs do not necessarily lead to a culturally-selected product (Glenn, 2004). Furthermore, discriminative stimuli within the IBCs of an interspecific cooperative hunting episode could have consisted of (a) human pointing gestures, such as arm movements; (b) body orientation, including head turns (i.e., communicative signals or cues); or (c) directional and/or mutual gazes between humans and proto-dogs. Conditional reinforcers that helped maintain these IBCs may have been movements or actions consequent of said gestures or gazes. Hence, the following of human gestures and gaze shifts, as well as the display of mutual gazes between humans and proto-dogs, seem to have appeared early during their association (i.e., "joint attention" can be defined as two individuals using gaze shifts to coordinate towards an event of interest; Bakeman \& Adamson, 1984; Dube, MacDonald, Mansfield et al., 2004; Kryzak, Bauer, Jones, \& Sturmey, 2013; Mongillo, Adamelli, Pitteri, \& Marinelli, 2015; Mongillo, Bono, Regolin, \& Marinelli, 2010; Pelaez, 2009; Range, Horn, Bugnyar, Gajdon, \& Huber, 2009; Savalli, Resende, \& Gaunet, 2016; Viranyi, Topal, Gacsi, Miklosi, \& Csanyi, 2004). The hypothesis that gaze- or gesturefollowing was reinforced by consequent movements of the addressee may help explain the controversy among experts about whether dogs acquired a heritable trait for following communicative gestures during domestication, or whether individual ontogeny and learning play a role in acquiring these skills (e.g., see Clark, Elsherif, \& Leavens [2019] for an indepth discussion of ontogeny versus phylogeny of canid and primate comparisons of Object Choice Tasks; Hare et al., 2010; Udell \& Wynne, 2010). The notion that modern humans have developed highly visible eyes (white sclera) for aiding intraspecific communication may have had relevance for the emergence of interspecific social-communication skills as well (Shipman, 2015). This notion is further supported by a recent study which found that grey wolves (high eye-visibility) spent more time gazing at other members of their social group than other canid species that had lower eye visibility (e.g., fennec foxes and bush dogs; Ueda et al., 2014). Ueda and colleagues (2014) concluded that the more visible the eyes are, the 
more that species uses them to communicate the direction of their gaze with each other. This "gaze signaling" can be found in highly social species (London, 2019).

Several studies have investigated dogs' abilities to follow human-provided gestures, such as pointing, touching or change in body orientation to locate hidden preferred items (e.g., food; Agnetta et al., 2000; Hare et al., 2002; Takaoka et al., 2015). It has been suggested that the process of domestication and resulting convergent evolution played a pivotal role in the development of social-communicative skills in both humans and dogs (e.g., Hare et al., 2002; Hare et al., 2010; Hare \& Tomasello, 2005; Miklosi \& Soproni, 2006), and that the ability of dogs to follow human pointing gestures is not dependent on ontogenetic experience (Gacsi et al., 2009; Hare et al., 2005; Riedel et al., 2008). Other studies (e.g., Dorey et al., 2010; Udell et al., 2008; Udell \& Wynne, 2010; Wynne et al., 2008), however, provided a more complete picture by acknowledging the significance of both phylogeny and ontogeny for the development of interspecific communication skills (Dorey et al., 2010; Udell \& Wynne, 2010). For instance, Dorey et al. (2010) found that puppies improve in following humanprovided pointing to find hidden food with time and maturation.

Additionally, there is evidence that dogs display indicative behaviors (e.g., gaze alternation) persistently to signal the location of a preferred object to a human who is unaware of the position of the hidden item (Gaunet, 2010; Hare et al.,1998; Kaminski et al., 2011; Miklosi et al., 2000; Worsley \& O’Hara, 2018). Miklosi et al. (2000) subsumed such behaviors under the umbrella term of "showing behavior" (i.e., gaze alternation including vocalizations and running back and forth between owner and location of hidden food). From a behavior-analytic perspective, however, canine showing behavior can be understood as "manding," which is one of the operant units of verbal behavior (Skinner, 1957). Manding is a verbal operant regulated by an establishing operation (e.g., deprivation, aversive stimulation, etc.) and a specific reinforcer (e.g., asking for a glass of water when thirsty and receiving it; Skinner, 1957). Kaminski et al. (2011) stated that based on the dogs' responses, the human participant started searching for the hidden object and found it mainly when the dog had an interest in it (e.g., the dog's interest "was tested in a short pre-phase prior to the onset of the experiment by playing with the dog"; Kaminski et al., 2011, p. 655). This statement highlights two important aspects when discussing basics of verbal behavior: (a) the establishment of social episodes that involve chains of social interactions between speaker and listener (i.e., IBCs where the dog is referred to as the speaker and the present human is the listener); and (b) manding is regulated by an establishing operation, such as being deprived of food or of a 
preferred item. The notion of interspecific social episodes and manding relations is explored in the following section.

The processes of domestication and concurrent artificial selection may have led to proto-dogs' tendency to behaviorally interlock with humans (Kukekova et al., 2014; Lord, Coppinger, \& Coppinger, 2014). During successive adoption of cooperative hunting strategies, early dogs are believed to have functioned as "catalysts" for the expansion of humans around the globe (e.g., Lupo, 2017; Shipman, 2015). The metacontingencies entailing interspecific cooperation during hunting episodes comprised IBCs that produced increases in food which had the triple function of (a) contributing to human natural selection (e.g., improved nutrition), (b) maintaining the operant behavior of humans and dogs participating in it, and (c) maintaining the interlocking contingencies that sustained over millennia. At least the latter two functions provided the bridge between behavioral and cultural selection processes, which eventually accounted for highly complex cultural entities (Glenn, 2003), such as contemporary dog-owning. The social-communicative skills of dogs, which also have relevance for current dog-owning practices, may originate in those early days when Upper Paleolithic peoples and their proto-dogs went hunting together.

\section{Human-dog family practices}

The fast-growing presence of dogs in worldwide households (e.g., near 35\% across 22 surveyed countries; Global GFK survey, 2016) has drawn considerable attention of researchers from different disciplines to understand the role of these animals in contemporary families (anthropology, sociology, psychology, and social work; e.g., Carlisle et al., 2018; Cimarelli et al., 2017; Maharaj \& Haney, 2015; Yeomans et al., 2019), to the point that it became one focus of the interdisciplinary field of anthrozoology (i.e., the study of human and nonhuman animal interactions from an interdisciplinary perspective; Podberscek et al., 2000; 2018). This has been especially the case considering the important changes during the last century in how people behave towards dogs (e.g., from keeping them outdoors as tools for hunting, hauling, and herding, to living with them indoors, talk "to" and "for" them, and buying them health insurance and birthday gifts; Irvine \& Cilia, 2017). The prominence of dogs in families, including the richness of the interactions that humans establish with them, and the mounting and diverse research findings available, offer an excellent opportunity to apply the behavior-analytic cultural-selection framework. 
Consistent with the view of other disciplines (e.g., sociology; Morgan, 1996), a behavior analytic approach to family entails assuming it not an object or a "thing," but as a set of practices with specific functions or meanings, which could include procreation, care, feeding, intimacy, relatedness, communication, or even violence. These are not simply "things that family members do; rather, the very doing of them constitutes family" (Irvine \& Cilia, 2017, p. 4). Accordingly, research on the role of dogs in families entails the analysis of how dogs participate in "doing" family.

Dogs are importantly embedded in a wide range of family practices (e.g., recreation, exercise, protection), among which child rearing seems to be a special case. Although this is consistent with frequent parent reports that they decided to adopt a dog for the "sake of the children" (Carlisle, 2015; Fifield \& Forsyth, 1999; Irvine \& Cilia, 2017; Muldoon et al., 2015; Tipper, 2011; Westgarth et al., 2007), the actual function of this practice (i.e., bringing a dog to the family) could on its own be the focus of behavior-analytic research.

The recurring IBCs entailed in dog-mediated child-rearing practices comprise, among other things, complex patterns of interrelated verbal and nonverbal behaviors of parents, children, dogs, and individuals outside the family (e.g., other children, relatives, veterinarians, animal trainers, etc.). As illustrated in the social episode depicted in Figure 2, these interactions happen in the context of different motivating operations for the individuals involved. For instance, a parent may observe that the dog has not been fed recently and draw the attention of the child and the dog to initiate an interactive episode (i.e., "indirect pet care"; Arhant et al., 2017). For the parent, this is the context of a child-rearing and dog-training episode, for the child it is a play-related scenario, and for the dog it is the context for feeding, playing, and social attention. Via modelling, instructions, and shaping, the parent shows the child how to cue the dog to sit or give their paw and provides reinforcement by saying "good dog," petting the dog, and providing a treat. The behavior of the parent and the dog are complex discriminative stimuli for the behavior of the child, who in successive trials echoes instructing "sit" and "give paw" and provides reinforcement to the proper responses displayed by the dog. The behavior of the child related to the behavior of the dog functions as conditioned reinforcement for the verbal and nonverbal behavior of the parent. The behavior of the parent in relation to the behavior of the dog reinforces the verbal and nonverbal behavior of the child. Moreover, other stimuli of the situation in which these episodes occur become conditional stimuli for future verbal and nonverbal behavior of the child directed 
towards the dog and the parent; often, it will be the child who initiates the interactive episodes, sometimes playing with the dog under active supervision.

The potential application of the proposed analysis is illustrated in research on dog-bite prevention strategies within and across families (Arhant et al., 2017). Several studies have found that parental guidance in dog-child interactions, such as teaching safe behaviors to the dog (see example above), indirect pet care (e.g., preparing dog food), and teaching the child when the dog needs a break (e.g., recognizing "appeasement signals" such as yawning, rapid lip licking or looking away; Firnkes et al., 2017) are important measures to limit risks of dog bites to children (Arhant et al., 2017; Meints \& DeKeuster, 2009; Purewal et al., 2017).

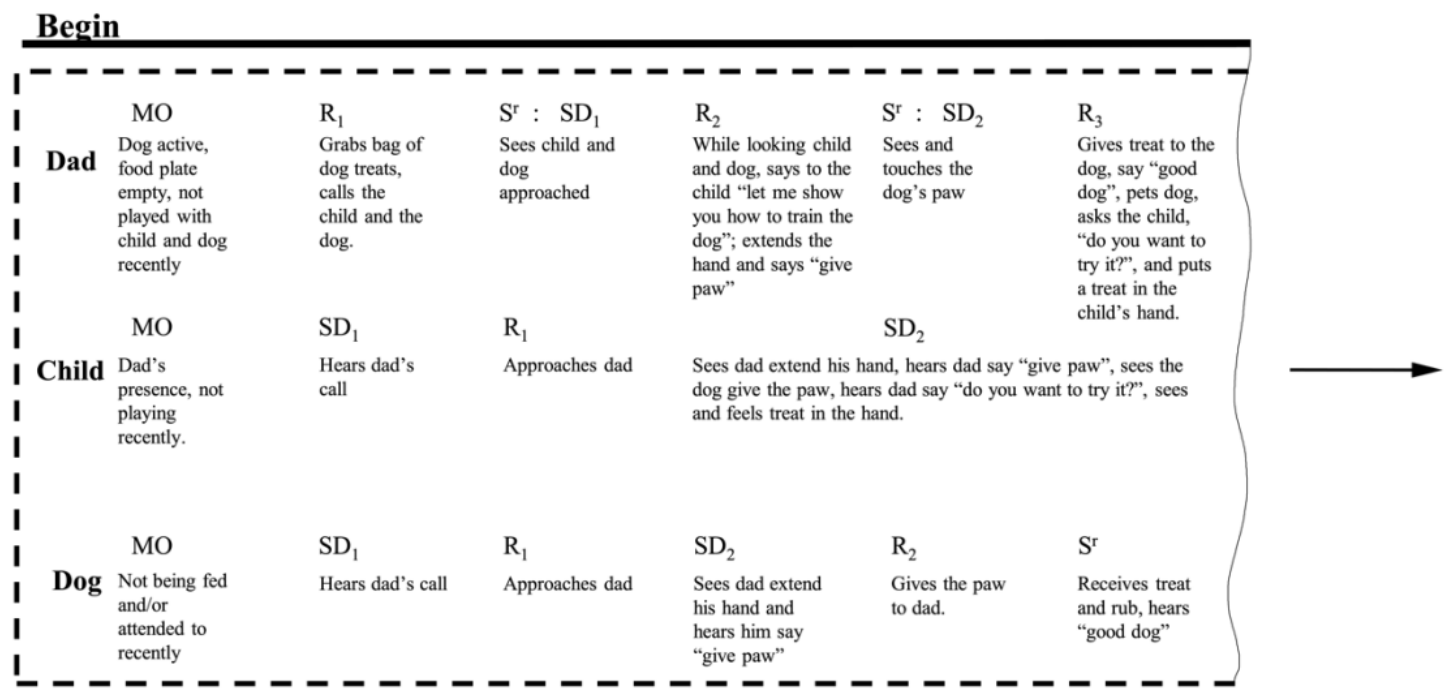

End

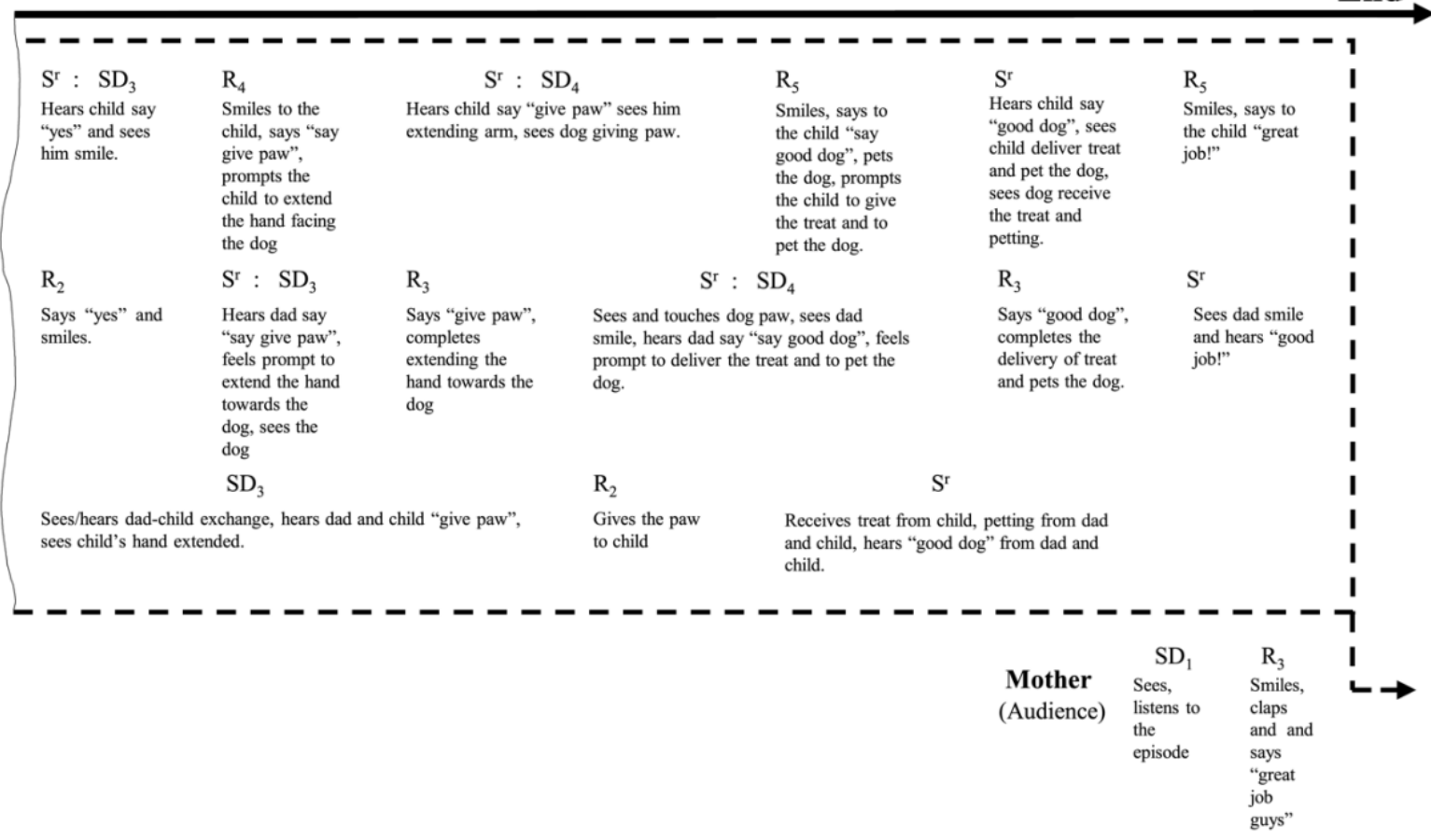


Figure 2. The dashed square represents an instance of a recurring interlocking behavioral contingency (IBC) involving the behavior of a parent, a child and a dog. In this social episode, the father instructs the child to train the dog to give the paw. These interactions happen in the context of specific motivating operations (MO) for each of the individuals involved (e.g., father and child have not played recently, the dog has not been feed or attended to recently). The responses of each participating individual $(\mathrm{R} 1, \mathrm{R} 2, \mathrm{R} 3, \ldots)$ are discriminative stimuli (SD1, SD2, SD3 ...) and reinforcers (Sr) for the behavior of the other individuals. For instance, the father's demonstration of how to ask the dog to give the paw (i.e., saying "give paw" and extending the hand), the dog responding correctly to the instruction (giving the paw), and the father delivering reinforcement (i.e., delivering a treat, petting and "good dog") is a complex discriminative stimulus for the behavior of the child. The behavior of the child, being consistent with the instruction of the father (e.g., echoing "give paw", extending the hand to the dog, delivering the treat, and saying "good"), provides in turn reinforcement to the behavior of both the father and the dog. An audience, in this example the mother, provides a consequence to the aggregate product of the social episode (e.g., praise for the cooperative performance). This type of recurring IBCs resulting in an aggregate product and its selection by the surrounding environment, illustrates the notion of metacontingencies in the context of family humandog interactions.

In terms of possible metacontingencies, aggregate products of these recurrent IBCs that could be selected by the surrounding environment (e.g., other family members as audiences) are the child's acquisition of new verbal or nonverbal behavior (e.g., a mother that observes the dog-training episode and at the end praises the "performance" of the group), the dog's acquisition of socially-valued behavior (e.g., a "well behaved" dog that gets to stay in the family), social facilitators, or reduction of stress levels of the members involved (e.g., Greenebaum, 2010; Kwan \& Bain, 2013; Odendaal \& Meintjes, 2003; Wells, 2004; Westgarth et al., 2015). Research on the positive effects of dogs' inclusion in families in terms of, for instance, strengthening family ties and intimacy, supports this interpretation (e.g., Cloutier \& Peetz, 2016; Power, 2008; Tannen, 2004; Turner, 2005). More importantly, these studies offer further opportunities of interpretation and new research following the selectionist framework here discussed. For instance, research into the analysis of parents' decision to adopt a dog suggests that it frequently is reported to be for the "sake of the children" (Carlisle, 2015; Fifield \& Forsyth, 1999). A behavior-analytic account would provide a functional understanding of actual controlling environmental and historical variables not only responsible for this practice (Carlisle, 2015; Fifield \& Forsyth, 1999; Irvine \& Cilia, 2017; Muldoon et al., 2015; Tipper, 2011; Westgarth et al., 2007), but other related phenomena, including keeping or relinquishing a dog when the consequences of its inclusion 
to the family do not match prior expectations (e.g., an outcome possibly understood from a behavior-analytic perspective making use of the notions of verbal and non-verbal behavior correspondence, differential consequences for rule-following, and self-control; Catania, Shimoff, \& Matthews, 1989; Hayes, Zettle, \& Rosenfarb, 1989).

Of note is the fact that under this approach, maintenance of behavioral practices depends not only on each individual's behavior or the effects on the environment in the operant contingencies maintaining the behavior of the others (IBCs), but also on the metacontingencies that select them. This seems relevant to the understanding of how sociallydesirable canine behavior, such as performing responses on cue (e.g., "give paw," "sit"), paying attention to the owner (e.g., gaze directed at owner), and engaging in calm behaviors (e.g., lying on a dog bed or walking on a loose leash) can be shaped and maintained through reinforcement-based training. Also, it provides insight into how undesired canine behavior, such as aggressive responses, destructive tendencies, excessive barking, or fearful behavior are developed, which often results in strain on the human-dog relationship (e.g., Mondelli, Prato-Previde, Verga, Levi, Magistrelli, \& Valsecchi, 2004; Kwan \& Bain, 2013; Protopopova \& Gunter, 2017). For instance, inadequate socialization of recently acquired dogs with humans and other animals living in the household or the development of inadvertent reinforcement contingencies could be potentially understood as IBCs entailing owners and dogs, which in turn may help us understand (and likely modify) the establishment and maintenance of problematic canine behavior that often results in relinquishment of dogs (Diesel et al., 2010; Irvine, 2015; Kwan \& Bain, 2013; Mills \& Zulch, 2010; Power, 2008; Protopopova \& Gunter, 2017; Protopopova et al., 2016).

Not only new practices (desirable or undesirable) are shaped with the inclusion of a dog into a family, mounting research has also shown that this process results in substantial changes in already-established practices. Family dogs greatly depend on the behavior of other members of the family (e.g., for food, walks, training, play, health), which inevitably changes the "doing" of routines such as waking-up and sleeping, exercising, recreation, feeding, budgeting, holiday planning, etc. Research indicates that the deep engagement observed in humans that bring dogs into their lives results in complex interactions involving emotional behavior that characterizes kinship relations (Charles, 2014, 2016; Charles \& Davies, 2008). The potential application of the three-level selection framework to interpret and guide basic and applied research based on this type of key findings is substantial. The prominence of dogs in the environment of children seems of special relevance in this regard because of its implications. Research has shown that children often behave towards dogs as if they were 
siblings (Charles, 2014; Power, 2008), speak to and speak for dogs through a unique language (Hirsh-Pasek \& Treiman, 1982; Melson, 2008), and often confide to a dog more than to other family members (University of Cambridge, 2015). On the other hand, dogs are frequently brought into families with the expectation that they will help children learn responsibility and kindness towards other individuals (Irvine \& Cilia, 2017). However, these notions have not been consistently supported by research (Angantyr et al., 2016; Daly \& Morton, 2003; Patterson-Kane \& Piper, 2009), a fact that calls for further investigation, to which behavior analysis could contribute using the selectionist framework here presented.

\section{Human-dog relationships: What have other disciplines found?}

Over the last two decades, different fields of research have investigated why dogs have been, and continue to be, successful in cohabitating with humans (Jung \& Pörtl, 2018). First, we consider how two interdisciplinary fields of research, namely anthrozoology (i.e., the study of human and nonhuman animal interactions) and comparative cognition (i.e., the study of cognitive, emotional and social skills of animals), assess and characterize human-dog interactions. Second, we show how their findings can be placed within a behavior-analytic framework.

\section{Anthrozoological model}

Anthrozoology focuses on the study of human and nonhuman animal interactions from an interdisciplinary perspective (Podberscek, 2018; The Anthrozoology Research Group, 2019). This model underscores the notions of "friendship" and "social support," and within its framework, companion dogs are considered social support, in and of themselves, as well as facilitators of social interactions between people (O'Haire, 2010). An explanation of how the terms social support and friendship are defined is warranted due to their centrality in this approach. While social support has been straightforwardly characterized as "providing companionship and buffering stress" (Duvall-Antonacopoulos \& Pychyl, 2008; Hall, Wright, Hames, PAWS Team, \& Mills, 2016; Kotrschal, Schöberl, Bauer, Thibeaut, \& Wedl, 2009; Krause-Parello, 2012; McConnell, Brown, Shoda, Stayton, \& Martin, 2011; McNicholas \& Collis, 2000; Westgarth et al., 2015), the term friendship has been shown to be more difficult to define (Miklosi, 2015; Prato-Previde \& Valsecci, 2014). According to Silk (2002), nonhuman animal friendship can be outlined as a form of alliance, where organisms engage in cooperative behavior with a tendency for sharing, and potentially providing social support. 
Companion dogs offer the latter in the form of non-judgmental support, acknowledgement and positive regard, as well as unconditional love (Friedmann et al., 1980; Kruger et al., 2004; Maharaj \& Haney, 2015).

Regarding the dogs' role of facilitating social interactions (Fine, 2004; McNicholas \& Collis, 2000), anthrozoological research has also found that companion dogs act as "social lubricants" (Gunter, 1999), evoking more friendly attention from others and helping to initiate conversations (McNicholas \& Collis, 2006; Wells, 2004). Accordingly, studies suggest that companion dogs benefit romantic relationships by playing a role in stress relief for couples and providing the opportunity to practice empathy (Cloutier \& Peetz, 2016; Walsh, 2009). Overall, the anthrozoological model emphasizes the notion that friendship and social-support provided by companion dogs enhance psychological and physical well-being via buffering stress and reducing loneliness in humans (Duvall-Antonacopoulos \& Pychyl, 2008; O'Haire, 2010).

\section{Comparative-cognition model}

Comparative cognition combines biological and psychological frameworks. Its main goal is to study cognitive, emotional and social skills of animals across different levels of complexity (e.g., neuronal, individual, and social; Messerli Research Institute, 2019). This model comprises attachment theory, including safe-haven effects (Ainsworth \& Witting,1969; Bowlby, 1972), to explain human-dog relationships. The approach proposes a link between attachment to a caregiver (i.e., seeking to gain and maintain a degree of proximity to the object of attachment, which can range from close physical contact to interaction or communication across distance; Ainsworth \& Bell, 1970) and the infants' responses to threat or distress. A standardized experimental test developed by Ainsworth and Witting (1969), aimed at classifying attachment relationships in humans. The resulting Strange Situation test (Ainsworth \& Bell, 1970) consists of controlled observations of a subject's response to being placed in an unfamiliar room, confronted with an unfamiliar adult, and exposed to three conditions of brief separations from the attachment figure (Prato-Previde \& Valsecchi, 2014). This procedure has led to the classification of at least three distinguishable categories or patterns of attachment, namely, secure, insecure-avoidant, and insecure-anxious (Strand, Vossen, \& Savage 2019).

Since the late 1990s, when the landmark study of attachment behavior in dogs was published (Topál et al., 1998), several canine-related studies have replicated and extended the 
application of attachment theory, in general, and the Strange Situation test, in particular (e.g., Mariti et al., 2013a; Mariti et al., 2013b; Prato-Previde et al., 2003; Rehn et al., 2013; Topál et al., 2005; Valsecchi et al., 2010; White et al., 2017). Overall, attachment theory and the Strange Situation test have been used to study human-dog relationships across different canine occupations (e.g., pet dogs and search and rescue dogs; Mariti et al., 2013b) and caregivers (e.g., puppy walker, trainer and blind owner; Valsecchi et al., 2010). Overall, studies have found that companion dogs, guide dogs, and search and rescue dogs develop healthy attachments to different caregivers as the dogs reach maturity, and those attachments stay intact across time even if disrupted by brief separations (Mariti et al., 2013b; Valsecchi et al., 2010; for a review see Rehn \& Keeling, 2016).

In the following section, we reflect on how behavior analysis could interpret, integrate and expand findings from the aforementioned frameworks. We propose to (a) analyze attachment and social support phenomena in terms of reinforcement contingencies and verbal behavior, and (b) describe potential applications of relevant measurement and analysis procedures, including functional analysis methods.

\section{Integration of frameworks}

Behavior analytic efforts to approach and build on the anthrozoological and comparativecognition research frameworks will most likely require a functional analysis of interactions typically studied under these traditions to identify and experimentally manipulate relevant IBCs entailing human-human, human-dog, dog-dog, and dog-other species interactions. In doing so, key notions of these models such as social support, attachment, friendship, and social facilitation should be interpreted in terms of basic behavioral principles. Analogous theoretical and experimental efforts have successfully expanded the behavior-analytic framework to other research fields-e.g., Skinner's analysis of language and problem solving (Skinner, 1957, 1984); Barnes-Holmes and colleagues analyses of different social processes, including prejudice and religion (Roche, Barnes-Holmes, \& Barnes-Holmes, 2001; BarnesHolmes \& Hayes, 2001). An excellent illustration of these efforts is provided by Epstein, Lanza, and Skinner's $(1980 ; 1981)$ series of experiments with pigeons, in which they modeled complex individual and social behavior that included problem solving, creativity, selfrecognition, symbolic communication, competition, and observational behavior. A common aspect across Epstein and colleagues' experiments that specifically targeted social interactions was the explicit dissection of the foundational individual operant repertories and the 
interlocking contingencies involved (Epstein, 1981). For instance, in Epstein et al.'s (1980) Jack and Jill experiment on symbolic communication, manding was trained in a pigeon named Jack and tacting in another pigeon named Jill. In a resulting typical IBC (i.e., social episode), Jack asked Jill for a color name by pecking on a "What color?" key, in response to which Jill looked through the curtain at a randomly-displayed hidden color and then pecked another key with a written name for the color while Jack watched. Jack produced reinforcement for Jill's behavior by pressing the "Thank you" key. We have presented a human-dog related illustration of this approach in Figure 2's analysis of a family interaction.

Notwithstanding the growing interest of non-behavior analytic research in companion dogs as a source of social support (e.g., Duvall-Antonacopoulos \& Pychyl, 2008; Friedmann, 1980; Hall et al., 2016; McConnell et al., 2011), only few studies have investigated this topic with experimental methodologies (e.g., Kotrschal et al., 2009; McNicholas \& Collis, 2000). Instead, the majority of studies have implemented indirect or qualitative approaches (e.g., focus groups, interviews, questionnaires or surveys) to investigate social support and general health effects of companion dogs on their owners (e.g., Hall et al., 2016; Maharaj \& Haney, 2015; McConnell et al., 2011; Westgarth et al., 2015). The lack of experimental research offers an ideal opportunity to implement behavior-analytic oriented research that could provide direct evidence of the positive effects of social support provided by dogs, and more importantly, develop systematic interventions that could maximize these effects (e.g., via direct measurement of relevant behaviors and identifying functionally relevant environmental events).

Promisingly, recent efforts to translate the notions of social support and attachment to a behavior-analytic perspective offer ideal precursors for approaching these notions specifically in the dog-human interaction context. For instance, Fryling's (2014) functional analysis of social support of caregivers concluded that social support relates to contexts in which one individual, the "recipient," interacts with another individual acting as the "provider" of social support. The provider responds to the behavior of the receiver by (a) being informative (i.e., correspondence between a rule and actual contingencies, with the recipient potentially following the rule because the provider is credible; Hayes et al., 1989), and (b) understanding and validating the recipient's experiences by displaying socially appropriate listener behavior (e.g., delivery of conditioned reinforcement and motivating operations in the form of praise, comforting or encouraging vocal or gesturing responses; Barnes-Holmes, O’Hora, Roche, Hayes, \& Bisset, 2001; Lewon \& Hayes, 2014). Analogous behavioral accounts of social support through companion dogs seem feasible. A starting point 
may be to operationally define social support (e.g., dogs providing non-contingent attention to their owners), and apply behavior-analytic methodologies (e.g., preference assessments, component analyses, functional analyses) to investigate the impact of social support within dyadic human-dog interactions. For example, a recent study assessed the reinforcer effectiveness of interaction with a therapy dog contingent and non-contingent on completion of academic material with children (Protopopova, Matter, Harris, Wiskow, \& Donaldson, 2019). Protopopova et al. (2019) conducted preference assessments and employed a multielement design comprising four different conditions (baseline, contingent leisure, noncontingent dog, and contingent dog) to detect the reinforcing properties of interactions with a therapy dog. Overall, the child's correct responding during the academic tasks increased when the interaction with the dog was presented contingently (Protopopova et al., 2019). Similar research approaches may be feasible for assessing social-support effects within the behavior-analytic framework.

Regarding attachment, Strand et al. (2019) defined it as relatively stable behavioral tendencies developed and maintained in contingencies that are characteristic of families. These contingencies encompass differential responses of parents or caregivers to the securityseeking behavior of infants. For example, a pattern of predictably responsive caregiving results in "secure attachment" (i.e., infant security-seeking responses are met with consistent caregiver behavior, which results in the child's reduction of negative emotional states; Strand et al., 2019). Alternatively, "insecure-avoidant attachment" arises from caregiving that is predictably unresponsive (i.e., extinction schedule), while "insecure-anxious attachment" is believed to stem from caregiving responses that are unpredictively responsive (i.e., variableratio schedules of reinforcement; Strand et al., 2019).

Although it has been repeatedly and consistently shown that humans and dogs form relationships that resemble attachment bonds (e.g., Mariti et al., 2013b; Rehn \& Keeling, 2016; Topál et al., 1998; Valsecchi et al., 2010), very few studies have investigated these relationships from a functional perspective. For example, Feuerbacher and Wynne (2016) used the functional analysis method (Iwata et al., 1982/1994) to assess the variables that are involved in human-dog interactions. More specifically, they investigated whether dogs would display an arbitrary response to get access to the owner, and potential motivating operations were manipulated in the functional analysis conditions (e.g., alone, owner attention, owner presence, bed, and toys). The results demonstrated that functional analyses can be used to assess the variables comprised in human-dog social interactions. It was further shown that access to the owner can reinforce companion dog behaviour (Feuerbacher \& Wynne, 2016). 
These findings are in line with Strand et al.'s (2019) behavioral account of human attachment styles (e.g., in a secure attachment style, infant security-seeking is met with consistent availability of the caregiver). Future research could extend on Feuerbacher and Wynne's (2016) and Strand and colleagues' (2019) findings by manipulating motivating operations related to social support or by implementing different schedules of reinforcement (e.g., variable ratio or extinction) to test the notions of attachment using differing reinforcement contingencies.

\section{Conclusion}

The present paper provided a primer on different models that have contributed to the understanding of the human-dog interactions (i.e., comparative cognition and anthrozoological). This is expected to aid experimental and applied behavior analysts who approach a field characterized by heterogeneous methodologies and theoretical discourses to which our discipline has not substantively contributed. In this vein, we discussed how the three-level selection by consequences framework - biological, behavioral, and cultural could be applied to understand different forms of human-dog interactions across those three levels. We illustrated this effort by discussing its application to specific interactions, including human-dog cooperation during hunting and child-rearing practices. In doing so, we suggested potential courses of conceptual, experimental and applied research. In this vein, investigating the function of the practice of bringing dogs into families (e.g., by functional analyses) seems to be a feasible and promising area of research.

Other lines of future research could attempt to interpret findings in other disciplines using a behavior analytic framework. These findings may include, but are not limited to, changes of human-dog interactions across different ages (e.g., from the Middle Ages to industrial revolution; Menache, 2005), changes in gender proportions in canine performance sports (e.g., Wlodarczyk, 2014, 2016), the impact of human-dog interactions and healthpromoting practices (e.g., Chen, 2018; Westgarth et al., 2014), the interactions with dogs in contemporary indigenous or native communities (e.g., Erikson, 2005; Jervis et al., 2018; Serpell, 2017), the relationship between positive child-dog interactions and other prosocial behavior (e.g., Cooke \& Farrington, 2016; Flynn, 2011) and the role of companion dogs in domestic violence settings (e.g., Fitzgerald, 2007; Gallagher et al., 2008), for example. 
Overall, the coherence of the behavior-analytic selectionist approach is a major strength that, when compared to other approaches, could greatly contribute synthesizing a great amount of scattered research on human-dog relationships conducted across various fields. This framework, in particular, can be applied to explain both historical accounts of the coevolution of prehistoric humans and proto-dogs, as well as investigating contemporary dogowning practices from a molar view. In turn, it seems possible that these efforts may trigger further reflection on the selectionist approach itself, including discussions on its potential extension to other phenomena and methodological refinements necessary to study behavior across the different levels of selection (e.g., Mattaini, 2006; Mattaini, 2019; Velasco, Benvenuti, \& Tomanari, 2012). 7410 words

\section{Disclosure of interest}

The authors report no conflict of interest.

Authors contributed equally to the preparation of this manuscript. 


\section{References}

Agnetta, B., Hare, B., \& Tomasello, M. (2000). Cues to food location that domestic dogs (Canis familiaris) of different ages do and do not use. Animal Cognition, 3, 107-112.

Ainsworth, M.D.S., \& Bell, S.M. (1970). Attachment, exploration and separation: illustrated by the behavior of one-year-olds in a strange situation. Child Development, 41(1), 49-67.

Ainsworth, M.D.S., \& Wittig, B.A. (1969). Attachment and exploratory behavior of one-year olds in a strange situation. In B.M. Foss (Ed.), Determinants of infant behavior (pp. 113136). London: Methuen.

Angantyr, M., Hansen, E. M., Eklund, J. H., \& Malm, K. (2016). Reducing sex differences in children's empathy for animals through a training intervention. Journal of Research in Childhood Education, https://doi.org/10.1080/02568543.2016.1178198

Arhant, C., Beetz, A.M., \& Troxler, J. (2017). Caregiver reports of interactions between children up to 6 years and their family dog - implications for dog bite prevention. Frontiers in Veterinary Science, https://doi.org/10.3389/fvets.2017.00130

Bakeman, R., \& Adamson, L.B. (1984). Coordinating attention to people and objects in mother-infant and peer-infant interaction. Child Development, 55, 1278-1289.

Barnes-Holmes, D., \& Hayes, S.C. (2001). Religion, spirituality, and transcendence. In S.C. Hayes \& D. Barnes-Holmes, Relational Frame Theory: A Post-Skinnerian Account of Human Language and Cognition (pp. 239-252). New York: Kluwer Academic Publishers.

Barnes-Holmes, D., O’Hora, D., Roche, B., Hayes, S.C., \& Bisset, R. (2001). Understanding and verbal regulation. In S.C. Hayes \& D. Barnes-Holmes, Relational Frame Theory: A Post-Skinnerian Account of Human Language and Cognition (pp. 103-118). New York: Kluwer Academic Publishers.

Bennett, S.L. (2013). Animal behavior case of the month. Journal of the American Veterinary Medical Association, 243(12), 1697-1699.

Bowlby, J. (1972). Attachment. Middlesex: Penguin Books.

Carlisle, G.K., Johnson, R.A., Mazurek, M., Bibbo, J.L., Tocco, F., \& Cameron, G.T. (2018). Companion animals in families of children with autism spectrum disorder: lessons learned from caregivers. Journal of Family Social Work, https://doi.org/10.1080/10522158.2017.1394413

Carlisle, G.K. (2015). Pet dog ownership decisions for parents of children with Autism Spectrum Disorder. Journal of Pediatric Nursing, 29(2), 114-123.

Catania, A. C. (2013). A Natural Science of Behavior. Review of General Psychology, 17(2), 133-139.

Catania, A.C., Shimoff, E., \& Matthews, B.A. (1989) An experimental analysis of rulegoverned behavior. In S. Hayes (Ed.), Rule-Governed Behavior (pp. 119-150). New York: Plenum Press.

Charles, N. (2016). Post-human families? Dog-human relations in the domestic sphere. Sociological Research Online, http://www.socresonline.org.uk/21/3/8.html. Accessed 05 January 2019.

Charles, N. (2014). 'Animals just love you as you Are': experiencing kinship across the species barrier. Sociology, https://doi.org/10.1177/0038038513515353

Charles, N., \& Davies, C. A. (2008). My family and other animals: pets as kin. Sociological Research Online, http://www.socresonline.org.uk/13/5/4.html. Accessed 05 January 2019.

Chen, E.Y. (2018). To a future where everyone can walk a dog even if they don't own one. Frontiers in Public Health, https://doi.org/10.3389/fpubh.2018.00349

Cimarelli, G., Turcsan, B., Range, F., \& Viranyi, Z. (2017). The other end of the leash: an experimental test to analyze how owners interact with their pet dogs. Journal of Visualized Experiments, https://www.jove.com/video/56233/the-other-end-leash-an-experimentaltest-to-analyze-how-owners. Accessed 18 October 2018. 
Clark, H., Elsherif, M.M., \& Leavens, D.A. (2019). Ontogeny vs. phylogeny in primate/canid comparisons: a meta-analysis of the Object Choice Task. Neuroscience and Biobehavioral Reviews, 105, 178-189. DOI: 10.1016/j.neubiorev.2019.06.001

Cloutier, A., \& Peetz, J. (2016). Relationships' best friend: links between pet ownership, empathy, and romantic relationship outcomes. Anthrozoös, https://doi.org/10.1080/08927936.2016.1181361

Clutton-Brock, J. (2017, $2^{\text {nd }}$ ed.). Origins of the dog: The archaeological evidence. In J. Serpell (Ed.), The Domestic Dog: Its Evolution, Behavior, and Interactions with People (pp. 8-21). Cambridge: Cambridge University Press.

Cooke, B.J., Farrington, D.P. (2016). The effectiveness of dog-training programs in prison: a systematic review and meta-analysis of the literature. The Prison Journal, 96(6), 854-876.

Coppinger, R., \& Coppinger, L. (2016). What is a Dog? Chicago: University of Chicago

Press.

Daly, B., \& Morton, L. L. (2003). Children with pets do not show higher empathy: a challenge to current views. Anthrozoös, 16, 298-314.

Delgado, D. (2012). The selection of a metaphor: the concepts of metacontingencies revisited. Revista Latinoamericana de Psicologia, 44(1), 13-24. http://www.scielo.org.co/scielo.php?script=sci_arttext\&pid=S0120-05342012000100002 Accessed 25 December 2018.

Diesel, G., Brodbelt, D., \& Pfeiffer, D.U. (2010). Characteristics of relinquished dogs and their owners at 14 rehoming centres in the United Kingdom. Journal of Applied Animal Welfare Science, https://doi.org/10.1080/10888700903369255

Dorey, N.R., Udell, M.A.R., \& Wynne, C.D.L. (2010). When do domestic dogs, Canis familiaris, start to understand human pointing? The role of ontogeny in the development of interspecies communication. Animal Behavior, https://doi.org/10.1016/j.anbehav.2009.09.032

Driscoll, C.A., Macdonald, D.W., O’Brien, S.J. (2009) From wild animals to domestic pets, an evolutionary view of domestication. Proceedings of the National Academy of Sciences of the United States, www.pnas.org"cgi"doi"10.1073"pnas.0901586106

Druzhkova, A.S., Thalmann, O., Trifonov, V.A., Leonard, J.A., Vorobieva, N.V., Ovodov, N.D., Graphodatsky, A.A., \& Wayne, R.K. (2013). Ancient DNA analysis affirms the canid from Altai as a primitive dog. PLoS ONE, https://doi.org/10.1371/journal.pone.0057754

Dube, W.V., MacDonald, R.P.F., Mansfield, R.C., Holcomb, W.L., \& Ahearn, W.H. (2004). Toward a behavioral analysis of joint attention. The Behavior Analyst, 27(2), 197-207.

Duvall-Antonacopoulos, N., \& Pychyl, T.A. (2008). An examination of the relations between social support, anthropomorphism and stress among dog owners. Anthrozoös, http://dx.doi.org/10.2752/175303708X305783

Edwards, T.L., Poling, A. (2011). Animal research in the Journal of Applied Behavior Analysis. Journal of Applied Behavior Analysis, 44(2), 409-412.

Epstein, R., Lanza, R.P., \& Skinner, B.F. (1980) Symbolic communication between two pigeons (Columba livia domestica). Science, 207, 543-545. Available from: https://www.studocu.com/en/document/uned/psicologia-del-aprendizaje/other/symboliccommunication-between-two-pigeons-epstein-lanza-skinner-1980/2308151/view

Epstein, R. (1981). On pigeons and people: a preliminary look at the Columban Simulation Project. The Behavior Analyst, 4(1), 43-55. DOI: 10.1007/bf03391851

Epstein, R., Lanza, R.P., \& Skinner, B.F. (1981) Self-awareness in the pigeon. Science, 212(4495), 695-696. DOI: 10.1126/science.212.4495.695

Erikson, P. (2005). The social significance of pet-keeping among Amazonian Indians. In A.L. Podberscek, E.S. Paul, \& J.A. Serpell (Eds.). Companion animals and us: exploring the relationships between people and pets (pp. 7-26). Cambride: Cambridge University Press. 
Fall, T., Kuja-Halkola, R., Dobney, K., Westgarth, C., Magnusson, P.K.E. (2019). Evidence of large genetic influences on dog ownership in the Swedish Twin Registry has implications for understanding domestication and health associations. Scientific Reports, 9, https://doi.org/10.1038/s41598-019-44083-9

Feuerbacher, E.N., \& Wynne, C.D.L. (2015). Shut up and pet me! Domestic dogs (Canis lupus familiaris) prefer petting to vocal praise in concurrent and single-alternative choice procedures. Behavioral Processes, http://dx.doi.org/10.1016/j.beproc.2014.08.019

Feuerbacher, E.N., \& Wynne, C.D.L. (2016) Application of functional analysis methods to assess human-dog interactions. Journal of Applied Behavior Analysis, 49(3), 1-5. DOI: 10.1002/jaba.318

Fifield, S.J., \& Forsyth, D.K. (1999). A pet for the children: factors related to family pet ownership. Anthrozoös, 12, 24-32.

Fine, A.H. (2004). The AAT Rx four youth: bridging research with clinical insight. AnimalAssisted Interventions in Adolescent Mental Health Conference, Philadelphia, USA. http://www.vet.upenn.edu/research/centers/cias/pdf/Proceedings.pdf. Accessed 20 January 2019.

Firnkes, A., Bartels, A., Bidoli, E., Erhard, M. (2017). Appeasement signals used by dogs during dog-human communication. Journal of Veterinary Behavior: Clincal Applications and Research, 19, 35-44.

Fitzgerald, A.J. (2007) "They gave me a reason to live": the protective effects of componion animals on the suicidality of abused women. Humanity and Society, 31, 355-378.

Flynn, C.P. (2011). Examining the links between animal abuse and human violence. Crime, Law and Social Change, 55, 453-468.

Friedmann, E., Katcher, A.H., Lynch, J.J., \& Thomas, S.A. (1980). Animal companions and one-year survival of patients after discharge from a coronary care unit. Public Health Reports, 95(4), 307-312.

Fryling, M.J. (2014) Contextual intervention for caregiver non-adherence with behavioral intervention plans. Child \& Family Behavior Therapy, 36(3), 191-203. DOI: 10.1080/07317107.2014.934172

Fukuzawa, M., \& Hashi, A. (2017). Can we estimate dogs' recognition of objects in mirrors from their behavior and response time? Journal of Veterinary Behavior: Clinical Applications and Research, https://doi.org/10.1016/j.jveb.2016.10.008

Gacsi, M., Kara, E., Belenyi, B., Topal, J., \& Miklosi, A. (2009). The effect of development and individual differences in pointing comprehension of dogs. Animal Cognition, 12, 471479.

Gallagher, B., Allen, M., Jones, B. (2008). Animal abuse and intimate partner violence: researching the link and its significance in Ireland - a veterinary perspective. Irish Veterinary Journal, https://doi-org.queens.ezp1.qub.ac.uk/10.1186/2046-0481-61-10-658

Gaunet, F. (2010). How do guide dogs and pet dogs (Canis familiaris) ask their owners for their toy and for playing? Animal Cognition, 13, 311-323.

Germonpre, M., Laznickova-Galetova, M., Sablin, M.V., \& Bocherens, H. (2018). Selfdomestication or human control? The Upper Palaeolithic domestication of the wolf. In C. Stepanoff \& J.-D Vigne (Eds.), Hybrid Cummunities. Biosocial Approaches to Domestication and Other Trans-species Relationships (pp. 1-31). London: Routledge.

Germonpre, M., Laznickova-Galetova, M., Jimenez, E.-L., Losey, R., Sablin, M., Bocherens, H., \& van den Broeck, M. (2017). Consumption of canid meat at the Gravettian Predmosti site, The Czech Republic. Fossil Imprint, 73(3-4), 360-382.

Germonpre, M., Laznickova-Galetova, M., Sablin, M., \& Bocherens, H. (2015). A comparison of two hypotheses of the domestication of the dog. Proceedings of the $5^{\text {th }}$ Annual Meeting of the European Society for the study of Human Evolution, London, UK. 
Germonpre, M., Sablin, M.V., Stevens, R.E., Hedges, R.E.M., Hofreiter, M., et al. (2009). Fossil dogs and wolves from Palaeolithic sites in Belgium, the Ukraine, and Russia: osteometry, ancient DNA and stable isotopes. Journal of Archaeological Science, https://doi.org/10.1016/j.jas.2008.09.033

Glenn, S.S. (1988). Contingencies and metacontingencies: towards a synthesis of behavior analysis and cultural materialism. The Behavior Analyst, 11(2), 161-179.

Glenn, S.S. (2003). Operant contingencies and the origin of cultures. In K.A. Lattal \& P.N. Chase (Eds.), Behavior Theory and Philosophy (pp. 223-242). New York: Kluwer Academic/Plenum Publishers.

Glenn, S.S. (2004). Individual Behavior, Culture, and Social Change. The Behavior Analyst, 27(2), 133-151.

Glenn, S.S. (2010). Metacontingencies, selection and OBM: comments on "Emergence and Metacontingency". Behavior and Social Issues, 19, 79-85.

Glenn, S.S., Malott, M.E., Abib-Andery, M.A.P., Benvenuti, M., Houmanfar, R.A., Sandaker, I., Todorov, J.C., Tourinho, E.Z., \& Vasconcelos, L.A. (2016). Toward consistent terminology in a behaviorist approach to cultural analysis. Behavior and Social Issues, https://doi.org/10.5210/bsi.v25i0.6634

Global GfK Survey (2016). Pet Ownership. https://www.gfk.com/fileadmin/user_upload/country_one_pager/NL/documents/GlobalGfK-survey_Pet-Ownership_2016.pdf. Accessed 10 January 2019.

Gray, P.B., Volsche, S.L., Garcia, J.R., \& Fisher, H.E. (2015). The roles of pet dogs and cats in human courtship and dating. Anthrozoös, https://doi.org/10.1080/08927936.2015.1064216

Greenebaum, J.B. (2010). Training dogs and training humans: symbolic interaction and dog training. Anthrozoös, 23(2), 129-141.

Grimm, D. (2017). These may be the world's first images of dogs - and they're wearing leashes. Science AAAS. https://www.sciencemag.org/news/2017/11/these-may-be-world-sfirst-images-dogs-and-they-re-wearing-leashes Accessed 6 January 2019.

Groeneveld, E. (2016). Prehistoric hunter-gatherer societies. Ancient History Encyclopedia, Article 911. https://www.ancient.eu/article/991/prehistoric-hunter-gatherer-societies/ Accessed 1 February 2019.

Guagnin, M., Perri, A.R., \& Petraglia, M.D. (2018). Pre-Neolithic evidence for dog-assisted hunting strategies in Arabia. Journal of Anthropological Achaeology, https://doi.org/10.1016/j.jaa.2017.10.003

Gunter, B. (1999). Pets and People: The Psychology of Pet Ownership. London: Publishers

Ltd.

Hall, N. (2017). Persistence and resistance to extinction in the domestic dog: basic research and applications to canine training. Behavioral Processes, https://doi.org/10.1016/j.beproc.2017.04.001

Hall, N., Protopopova, A., \& Wynne, C.D.L. (2015). The role of environment and ownerprovided consequences in canine stereotypy and compulsive disorder. Journal of Veterinary Behavior: Clinical Applications and Research, http://dx.doi.org/10.1016/j.jveb.2014.10.005

Hare, B., Rosati, A., Kaminski, J., Bräuer, J., Call, J., \& Tomasello, M. (2010). The domestication hypothesis for dogs' skills with human communication: a response to Udell et al. (2008) and Wynne et al. (2008). Animal Behavior, e1-e6.

Hare, B., Plyusnina, I., Ignacio, N., Schepina, O., Stepika, A., Wrangham, R., \& Trut, L. (2005). Social cognitive evolution in captive foxes is a correlated by-product of experimental domestication. Current Biology, 15, 226-230.

Hare, B., \& Tomasello, M. (2005) Human-like social skills in dogs? Trends in Cognitive Sciences, https://doi.org/10.1016/j.tics.2005.07.003 
Hare, B., Brown, M., Williamson, C., \& Tomasello, M. (2002). The domestication of social cognition in dogs. Science, 298, 1634-1636.

Hare, B., Call, J., \& Tomasello, M. (1998). Communication of food location between human and dog (Canis familiaris). Evolution of Communication, 2, 137-159.

Hayes, S.C., Zettle, R.D., \& Rosenfarb, I. (1989) Rule-following. In S.C. Hayes (Ed.), RuleGoverned Behavior: Cognition, Contingencies, and Instructional Control (pp. 191-220). Boston: Springer. DOI: 10.1007/978-1-4757-0447-1_6

Hirsh-Pasek, K., \& Treiman, R. (1982). Doggerel: Motherese in a new context. Journal of Child Language, 9, 229-237.

Hull, D.L., Langman, R.E., Glenn, S.S. (2001). A general account of selection: Biology, immunology, and behavior. Behavioral and Brain Sciences, 24, 511-573. DOI: $10.1017 / \mathrm{S} 0140525 \mathrm{X} 0156416 \mathrm{X}$

Irvine, L. (2015). Animal sheltering. In L. Kalof (Ed.), The Oxford handbook of animal studies. http://www.

oxfordhandbooks.com/view/10.1093/oxfordhb/9780199927142.001.0001/oxfordhb9780199927142-e-12. Accessed 25 January 2019.

Irvine, L., \& Cilia, L. (2017). More-than-human families: pets, people, and practices in multispecies households. Sociology Compass, 11, https://doi.org/10.1111/soc4.12455

Iwata, B.A., Dorsey, M.F., Slifer, K.J., Bauman, K.E., \& Richman, G.S. (1994). Toward a functional analysis of self-injury. Journal of Applied Behavior Analysis, 27, 197-209. DOI: 10.1901/jaba.1994.27-197

Jung, C., \& Pörtl, D. (2018). Scavanging hypothesis: lack of evidence for dog domestication on the waste dump. Dog Behavior, 2, https://doi.org/10.4454/db.v4i2.73

Jervis, L.L., Warren, D., Salois, E.M., Ketchum, S., Tallbull, G., \& Spicer, P. (2018). Protectors, aggressors, and kinfolk: dogs in a tribal community. Anthrozoös, https://doi.org/10.1080/08927936.2018.1455452

Kaminski, J., Neumann, M., Bräuer, J., Call, J., \& Tomasello, M. (2011). Dogs, Canis familiaris, communicate with humans to request but not to inform. Animal Behavior, https://doi.org/10.1016/j.anbehav.2011.06.015

Koler-Matznick, J. (2002). The origin of the dog revisited. Anthrozoös, 15(2), 98-118.

Kotrschal, K., Schöberl, I., Bauer, B., Thibeaut, A-M., Wedl, M. (2009). Dyadic relationships and operational performance of male and female owners and their male dogs. Behavioral Processes, 81, 383-391. DOI: 10.1016/j.beproc.2009.04.001

Kruger, K.A., Trachtenberg, S.W., \& Serpell, J.A. (2004). Can animals help humans heal? Animal-assisted interventions in adolescent mental health. Center for Interaction of Animals and Society (CIAS) and University of Pennsylvania School of Veterinary Medicine, Philadelphia, PA.

Kryzak, L.A., Bauer, S., Jones, E.A., \& Sturmey, P. (2013). Increasing responding to others' joint attention directives using circumscribed interests. Journal of Applied Behavior Analysis, 46(3), 674-679. DOI: 10.1002/jaba.73

Kukekova, A.V., Trut, L.N., Acland, G.M. (2014). Genetics of domesticated behavior in dogs and foxes. In T. Grandin \& M.J. Deesing (Eds.), Genetics and the Behavior of Domestic Animals (pp. 361-396). London: Academic Press.

Kwan, J.Y., \& Bain, M.J. (2013). Owner attachment and problem behaviors related to relinquishment and training techniques of dogs. Journal of Applied Animal Welfare Science, https://doi.org/10.1080/10888705.2013.768923

Larson, G., Karlsson, E.K., Perri, A.R., Webster, M.T., Ho, S.Y.W., Peters, J., Stahl, P.W., Piper, P.J., Lingaas, F., Fredholm, Merete, et al. (2012). Rethinking dog domestication by integrating genetics, archeology, and biogeography. Proceedings of the National Academy of Sciences of the United States of America, https://doi.org/10.1073/pnas.1203005109 
Leathlobhair, M.N., Perri, A.R., Irving-Pease, E.K., Witt, K.E., Linderholm, A., Haile, J., Lebrasseur, O., Ameen, C., Blick, J., Boyko, A.R. et al. (2018). The evolutionary history of dogs in the Americas. Science, 361, 81-85.

Lescureux, N. (2018). Beyond wild and domestic: human complex relationships with dogs, wolves, and wolf-dog hybrids. In C. Stepanoff \& J.-D. Vigne (Eds.), Biosocial Approaches to Domestication and Other Transspecies Relationships (pp. 83-98). London: Routledge.

Lewon, M. \& Hayes, L.J. (2014). Toward an analysis of emotions as products of Motivating Operations. Psychological Record, 64, 813-825. DOI: 10.1007/s40732-014-0046-7

London, K. (2019). Canid sociality seen in their eyes. Bark - the dog culture magazine. https://thebark.com/content/canid-sociality-seen-theireyes?fbclid=IwAR1oXcbhdr8t4lwqFJKu5QTBXJMHwNfz1QCI6FWREOqCd6dep406nF 6PLBs. Accessed 1 February 2019.

Lord, K., Coppinger, L., Coppinger, R. (2014). Differences in the behavior of landraces and breeds of dogs. In T. Grandin \& M.J. Deesing (Eds.), Genetics and the Behavior of Domestic Animals (pp. 195-235). London: Academic Press.

Lord, K., Schneider, R.A., Coppinger, R. (2017). Evolution of working dogs. In J. Serpell (Ed.), The Domestic Dog: Its Evolution, Behavior, and Interactions with People (pp. 4266). Cambridge: Cambridge University Press.

Lupo, K.D. (2017). When and where do dogs improve hunting productivity? The empirical record and some implications for early Upper Palaeolithic prey acquisition. Journal of Anthropological Archaeology, https://doi.org/10.1016/j.jaa.2017.05.003

Maharaj, N., \& Haney, C.J. (2015). A qualitative investigation of the significance of companion dogs. Western Journal of Nursing Research, https://doi.org/10.1177/0193945914545176

Mariti, C., Ricci, E., Zilocchi, M., \& Gazzano, A. (2013a). Owners as a secure base for their dogs. Behavior, 150(11), 1275-1294.

Mariti, C., Ricci, E., Carlone, B., Moore, J.L., Sighieri, C., \& Gazzano, A. (2013b). Dog attachment to man: a comparison between pet and working dogs. Journal of Veterinary Behavior: Clinical Applications and Research, https://doi.org/10.1016/j.jveb.2012.05.006

Mattaini, M.A. (2019). Out of the lab: Shaping an ecological and constructional cultural systems science. Perspectives on Behavior Science, 42, 713-731. DOI: 10.1007/s40614019-00208-z

Mattaini, M.A. (2006). Will cultural analysis become a science? Behavior and Social Issues, https://doi.org/10.5210/bsi.v15i1.380

McConnell, A.R., Brown, C.M., Shoda, T.M., Stayton, L.E., Martin, C.E. (2011). Friends with benefits: on the positive consequences of pet ownership. Journal of Personality and Social Psychology, 101(6), 1239-1252. DOI: 10.1037/a0024506

McNicholas, J., \& Collis, G.M. (2000). Dogs as catalysts for social interactions: robustness of the effect. British Journal of Psychology, 91, 61-70.

McNicholas, J., \& Collis, G.M. (2006). Animals as social supports: insights for understanding animal-assisted therapy. In A.H. Fine (Ed.), Handbook on Animal-Assisted Therapy: Theoretical Foundations and Guidelines for Practice (pp. 49-71). San Diego: Academic Press.

Meints, K., \& DeKeuster, T. (2009). Brief report: don't kiss a sleeping dog: the first assessment of "The Blue Dog" bite prevention program. Journal of Pediatric Psychology, https://doi.org/10.1093/jpepsy/jsp053

Melson, G. F. (2008). Children in the living world: Why animals matter for children's development. In A. Fogel, B.J. King, \& S.G. Shanker, (Eds.), Human development in the twenty-first century (pp. 147-154). Cambridge: Cambridge University Press. 
Menache, S. (2005). Hunting and attachment to dogs in the Pre-Modern Period. In A.L. Podberscek, E.S. Paul, \& J.A. Serpell (Eds.). Companion animals and us: exploring the relationships between people and pets (pp. 42-60). Cambride: Cambridge University Press.

Messerli-Research Institute (2019). Comparative Cognition. https://www.vetmeduni.ac.at/en/messerli/science/cognition/ Accessed 10 January 2019.

Miklosi, A. (2015). Dog Behavior, Evolution, and Cognition. Oxford Scholarship Online. DOI: 10.1093/acprof:oso/9780199646661.001.0001 Accessed 29 December 2018.

Miklosi, A., \& Soproni, K. (2006). A comparative analysis of animals' understanding of the human pointing gesture. Animal Cognition, https://doi.org/10.1007/s10071-005-0008-1

Miklosi, A., Polgardi, R., Topal, J., \& Csanyi, V. (2000). Intentional behavior in dog-human communication: an experimental analysis of 'showing' behavior in the dog. Animal Cognition, 3, 159-166.

Mills, D.S., \& Zulch, H. (2010) Veterinary medicine and animal behaviour: barking up the right tree! The Veterinary Journal, 183, 119-120. DOI: 10.1016/j.tvj1.2009.03.019

Mondelli, F., Prato-Previde, E., Verga, M., Levi, D., Magistrelli, S., Valsecchi, P. (2004) The bond that never developed: adoption and relinquishment of dogs in a rescue shelter. Journal of Applied Animal Welfare Science, 7(4), 253-266.

Mongillo, P., Adamelli, S., Pitteri, E., \& Marinelli, L. (2015). Reciprocal attention of dogs and owners in urban contexts. Journal of Veterinary Behavior: Clinical Applications and Research, 9, 158-163.

Mongillo, P., Bono, G., Regolin, L., \& Marinelli, L. (2010). Selective attention to humans in companion dogs, Canis familiaris. Animal Behaviour, 80, 1057-1063.

Morey, D., \& Jeger, R. (2015). Paleolithic dogs: why sustained domestication then? Journal of Archaeological Science: Reports, https://doi.org/10.1016/j.jasrep.2015.06.031

Morgan, D. (1996). Family Connections: An Introduction to Family Studies. Cambridge:

Polity Press

Muldoon, J.C., Williams, J.M., \& Lawrence, A. (2015). 'Mum cleaned it and I just played with it': children's perceptions of their roles and responsibilities in the care of family pets. Childhood, https://doi.org/10.1177/0907568214524457

Odendaal, J.S.J., \& Meintjes, R.A. (2003). Neurophysiological correlates of affiliative behavior between humans and dogs. The Veterinary Journal, https://doi.org/10.1016/S1090-0233(02)00237-X

O'Haire, M. (2010). Companion animals and human health: benefits, challenges, and the road ahead. Journal of Veterinary Behavior: Clinical Applications and Research, https://doi.org/10.1016/j.jveb.2010.02.002

Ovodov, N.D., Crockford, S.J., Kuzmin, Y.V., Higham, T.F.G., Hodgins, G.W.L., \& van der Plicht, J. (2011). A 33,000-year-old incipent dog from the Altai Mountains of Siberia: evidence of the earliest domestication disrupted by the last glacial maximum. PLoS ONE, https://doi.org/10.1371/journal.pone.0022821

Patterson-Kane, E. G., \& Piper, H. (2009). Animal abuse as a sentinel for human violence: a critique. Journal of Social Issues, https://psycnet.apa.org/doi/10.1111/j.15404560.2009.01615.x

Pear, J. (2016). The science of learning (2nd ed.). New York: Taylor and Francis.

Pelaez, M. (2009). Joint Attention and Social Referencing in Infancy as Precursors of Derived Relational Responding. In R.A. Rehfeldt, \& Y. Barnes-Holmes (Eds.), Derived Relational Responding Applications for Learners with Autism and other Developmental Disabilities: A Progressive Guide to Change (pp. 63-78). Oakland, CA, USA: New Harbinger Publications, Inc.

Perri, A.R. (2016). Hunting dogs as environmental adaptations in Jomon Japan. Antiquity, https://doi.org/10.15184/aqy.2016.115 
Persson, M.E., Sundman, A.-S., Hallden, L.-L., Trottier, A.J., \& Jensen, P. (2018). Sociality genes are associated with human-directed social behavior in golden and Labrador retriever dogs. PeerJ, https://doi.org/10.7717/peerj.5889

Pfaller-Sadovsky, N., Medina, L.G., \& Hurtado-Parrado, C. (2017). It is mine! Using clicker training as a treatment of object guarding in 4 companion dogs (Canis lupus familiaris). Journal of Veterinary Behavior: Clinical Applications and Research, https://doi.org/10.1016/j.jveb.2017.08.002

Pierce, W., \& Cheney, C. D. (2017). Behavior analysis and learning (6th ed.). New York:

Taylor and Francis.

Pierotti, R., \& Fogg, B.R. (2017). The First Domestication: How Wolves and Humans Coevolved. New Haven: Yale University Press.

Podberscek, A. (2018) Defining Anthrozoology. Animals and Society Institute. Available from https://www.animalsandsociety.org/human-animal-studies/defining-human-animalstudies-an-asi-video-project/defining-anthrozoology-with-anthony-podberscek/ Accessed January 102019.

Podberscek, A. L., Paul, E. S., \& Serpell, J. A. (2000). Introduction. In A.L. Podberscek, E.S. Paul, \& J. A. Serpell (Eds.), Companion Animals and Us: Exploring the Relationships between People and Pets (pp. 1-6). Cambridge: Cambridge University Press.

Power, E. (2008). Furry families: Making a human-dog family through home. Social and Cultural Geography, 9(5), 535-555.

Prato-Previde, E., \& Valsecchi, P. (2014). The Immaterial Cord: The Dog-Human Attachment Bond. In J. Kaminski \& S. Marshall-Pescini (Eds.), The Social Dog: Behavior and Cognition (pp. 165-189). London: Elsevier Inc.

Prato-Previde, E., Custance, D.M., Spiezio, C., \& Sabatini, F. (2003). Is the dog-human relationship an attachment bond? An observational study using Ainsworth's Strange Situation. Behavior, 140(2), 225-254.

Protopopova, A., \& Gunter, L.M. (2017). Adoption and relinquishment interventions at the animal shelter: a review. Animal Welfare, 26, 35-48.

Protopopova, A., Matter, A.L., Harris, B.N., Wiskow, K.M., Donaldson, J.M. (2019). Comparison of contingent and noncontingent access to therapy dogs during academic tasks in children with autism spectrum disorder. Journal of Applied Behavior Analysis. DOI: 10.1002/jaba.619

Protopopova, A., Kisten, D., \& Wynne, C. (2016). Evaluating a humane alternative to the bark collar: automated differential reinforcement of not barking in a home-alone setting. Journal of Applied Behaivor Analysis, https://doi.org/10.1002/jaba.334

Purewal, R., Christley, R., Kordas, K., Joinson, C., Meints, K., Gee, N., \& Westgarth, C. (2017). Companion animals and child/adolescent development: a systematic review of the evidence. International Journal of Environmental Research and Public Health, https://doi.org/10.3390/ijerph14030234

Range, F., Horn, L., Bugnyar, T., Gajdon, G.K., \& Huber, L. (2009). Social attention in keas, dogs, and human children. Animal Cognition, 12, 181-192.

Rehn, T., \& Keeling, L.J. (2016). Measuring dog-owner relationships: crossing boundaries between animal behavior and human psychology. Applied Animal Behavior Science, https://doi.org/10.1016/j.applanim.2016.07.003

Rehn, T., McGowan, R.T.S., \& Keeling, L.J. (2013). Evaluating the Strange Situation Procedure (SSP) to assess the bond between dogs and humans. PLoS One, https://doi.org/10.1371/journal.pone.0056938

Riedel, J., Schumann, K., Kaminski, J., Call, J., \& Tomasello, M. (2008). The early ontogeny of human-dog communication. Animal Behavior, https://doi.org/10.1016/j.anbehav.2007.08.010 
Roche, B., Barnes-Holmes, D., \& Barnes-Holmes, Y. (2001). Social processes. In S.C. Hayes \& D. Barnes-Holmes, Relational Frame Theory: A Post-Skinnerian Account of Human Language and Cognition (pp. 197-210). New York: Kluwer Academic Publishers.

Savalli, C., Resende, B., \& Gaunet, F. (2016). Eye contact is crucial for referential communication in pet dogs. PLoS ONE, 11(9), e0162161. DOI: 10.1371/journal.pone.0162161

Savolainen, P., Zhang, Y., Luo, J., Lundeberg, J., \& Leitner, T. (2002). Genetic evidence for an East Asian origin of domestic dogs. Science, 298(5598), 1610-1913.

Seksel, K., \& Lindeman, M.J. (2001). Use of clomipramine in treatment of obsessivecompulsive disorder, separation anxiety and noise phobia in dogs: a preliminary, clinical study. Australian Veterinary Journal, 79(4), 252-256.

Serpell, J. (2017). From paragon to pariah: cross-cultural perspectives on attitudes to dogs. In J. Serpell (Ed.), The Domestic Dog: Its Evolution, Behavior, and Interactions with People (pp. 300-315). Cambridge: Cambridge University Press.

Shipman, P. (2015). The Invaders: How Humans and Their Dogs Drove Neanderthals to Extinction. Cambridge, MA: Harvard University Press.

Shipman, P. (2014) How do you kill 86 mammoths? Taphonomic investigations of mammoth megasites. Quaternary International, https://doi.org/10.1016/j.quaint.2014.04.048

Silk, J.B. (2002). Using the 'F'-word in primatology. Behavior, 139, 421-446.

Skinner, B.F. (1987). Why we are not acting to save the world. In B.F. Skinner (Ed.), Upon Further Reflection (pp. 1-14). Englewood Cliffs, NJ: Prentice-Hall.

Skinner, B. F. (1984). The evolution of behavior. Journal of the Experimental Analysis of Behavior, 41(2), 217-221.

Skinner, B. F. (1981). Selection by consequences. Science, 213(4507), 501-504.

Skinner, B.F. (1957). Verbal behavior. New York: Appleton-Century-Crofts.

Strand, P.S., Vossen, J.J., Savage, E. (2019) Culture and child attachment patterns: a behavioral systems synthesis. Perspectives on Behavior Science. DOI: https://doi.org/10.1007/s40614-019-00220-3

Takaoka, A., Maeda, T., Hori, Y., \& Fujita, K. (2015). Do dogs follow behavioral cues from an unreliable human? Animal Cognition, https://doi.org/10.1007/s10071-014-0816-2

Tannen D. (2004). Talking the dog: framing pets as interactional resources in family discourse. Research on Language and Social Interaction, https://doi.org/10.1207/s15327973rlsi3704_1

Tanabe, Y. (2006). Phylogenetic studies of dogs with emphasis on Japanese and Asian breeds. Proceedings of the Japan Academy, Series B Physical and Biological Sciences, 85(10), pp375-387.

The Anthrozoology Research Group (2019). La Trobe University, Bendigo, Australia. http://www.anthrozoologyresearchgroup.com. Accessed 10 January 2019.

Thalmann, O., Shapiro, B., Cui, P., Schuenemann, V.J., Sawyer, S.K., Greenfield, D.L., Germonpré, M.B., Sablin, M.V., López-Giráldez, F., Domingo-Roura, X., Napierala, H., Uerpmann, H.-P., Loponte, D.M., Acosta, A.A., Giemsch, L., Schmitz, R.W., Worthington, B., Buikstra, J.E., Drushkova, A., Graphodatsky, A.S., Ovodov, N.D., Wahlberg, N., Freedman, A.H., Schweizer, R.M., Koepfli, K.-P., Leonard, J.A., Meyer, M., Krause, J., Pääbo, S., Green, R.E., Wayne, R.K. (2013). Complete mitochondrial genomes of ancient canids suggest a European origin of domestic dogs. Science, 342(6160), 871-874.

The Kennel Club (2019) Breed information centre. https://www.thekennelclub.org.uk/services/public/breed/Default.aspx Accessed 3 February 2019.

Tipper, B. (2011). 'A dog who I knew quite well': everyday relationships between children and animals. Children's Geogrphies, https://doi.org/10.1080/14733285.2011.562378 
Taylor, O., Audenaert, K., Baeken, C., Saunders, J., \& Peremans, K. (2016). Nuclear medicine for the investigation of canine behavioral disorders. Journal of Veterinary Behavior: Clinical Applications and Research, 16, 94-103.

Topál, J., Gasci, M., Miklosi, A., Viranyi, S., Kubinyi, E., \& Csanyi, V. (2005). Attachment to humans: a comparative study on hand-reared wolves and differently socialized dog puppies. Animal Behavior, 70(6), 1367-1375.

Topál, J., Miklosi, A., Csanyi, V., \& Doka, A. (1998). Attachment behavior in dogs (Canis lupus familiaris): a new application of Ainsworth's (1969) strange situation test. Journal of Comparative Psychology, 112(3), 219-229.

Turner, W.G. (2005) The role of companion animals throughout the family life cycle. Journal of Family Social Work, 9(4), 11-21.

Udell, M.A.R., \& Wynne, C.D.L. (2010). Ontogeny and phylogeny: both are essential to human-sensitive behavior in the genus Canis. Animal Behavior, 79(2), e9-e14.

Udell, M.A.R., Dorey, N.R., \& Wynne, C.D.L. (2008). Wolves outperform dogs in following human social cues. Animal Behavior, 76, 1767-1773.

Ueda, S., Kumagai, G., Otaki, Y., Yamaguchi, S., \& Kohshima, S. (2014). A comparison of facial color pattern and gazing behavior in canid species suggest gaze communication in gray wolves (Canis lupus). PLoS ONE, 9(6), e98217.

University of Cambridge (2015). Children often have a closer relationship with their pet than their siblings. Science Daily. www.sciencedaily.com/releases/2015/05/150513135011.htm. Accessed 25 January 2019.

Valsecchi, P., Prato-Previde, E., Accorsi, P.A., \& Fallani, G. (2010). Development of the attachment bond in guide dogs. Applied Animal Behavior Science, 123, 43-50.

Van Herwijnen, I.R., van der Borg, J.A.M., Naguib, M., \& Beerda, B. (2018). The existence of parenting styles in the owner-dog relationship. PLoS ONE, 13(2), e0193471.

Velasco, S.M., Benvenuti, M.F., \& Tomanari, G.Y. (2012). Metacontingencies, experimentation and nonhumans: Searching for conceptual and methodological advances. Revista Latinoamericana de Psicologia, 44(1), 25-34.

Vila, C., Savolainen, P., Madonado, J.E., Amorim, I.R., Rice, J.E., Honeycutt, R.L., Crandall, K.A., Lundeberg, J., \& Wayne, R.K. (1997). Multiple and ancient origins of the domestic dog. Science, 276(5319), 1687-1689.

Viranyi, Z., Topal, J., Gacsi, M., Miklosi, A., \& Csanyi, V. (2004). Dogs respond appropriately to cues of humans' attentional focus. Behavioral Processes, 66, 161-172.

Walsh, F. (2009). Human-animal bonds II: the role of pets in family systems and family therapy. Family Process, 4, 481-499.

Wells, D.L. (2004). The facilitation of social interactions by domestic dogs. Anthrozoös, 17, 340-353.

Westgarth, C., Christley, R.M., \& Christian, H.E. (2014). How might we increase physical activity through dog walking?: a comprehensive review of dog walking correlates. International Journal of Behavioral Nutrition and Physical Activity, https://doi.org/10.1186/1479-5868-11-83

Westgarth, C., Christian, H.E., \& Christley, R.M. (2015). Factors associated with daily walking of dogs. BMC Veterinary Research, 11(116), 1-13.

Westgarth, C., Pinchbeck, G.L., Bradshaw, J.W.S., Dawson, S., Gaskell, R.M., \& Christley, R.M. (2007). Factors associated with dog ownership and contact with dogs in a UK community. BMC Veterinary Research, 3(5), 1-9.

White, N., Mills, D., \& Hall, S. (2017). Attachment style is related to quality of assistance dog owners. International Journal of Environmental Research and Public Health, 14(6), 658-666.

White, P. (2018). (Un)Regulated Relations: an ethnographic perspective of dog ownership on Isla Mujeres, Mexico. Anthrozoös, 31(5), 615-625. 
Wlodarczyk, J. (2016). Post-communist canine: a feminist approach to women and dogs in canine performance sports in Poland. Society \& Animals, 24, 129-152.

Wlodarczyk, J. (2014). Strefy kontaktu, strefy władzy. Feministyczna analiza relacji kobiet i psów w sportach kynologicznych w Polsce [Contact zones, power zones. A feminist analysis of women and dogs in canine performance sports in Poland]. In M. P. Pregowski \& J. Wlodarczyk (Eds.), Pies też człowiek? Relacje psów i ludzi we współczesnej Polsce (pp. 114-151). Gdańsk: WN Katedra.

Worsley, H.K., O'Hara, S.J. (2018). Cross-species referential signaling events in domestic dogs (Canis familiaris). Animal Cognition, 27, https://doi.org/10.1007/s10071-018-1181-3

Wynne, C.D.L., Udell, M.A.R., \& Lord, K.A. (2008). Ontogeny's impact on human-dog communication. Animal Behavior, 76, e1-e4.

Yamamoto, M., Kikusui, T., \& Ohta, M. (2009). Influence of delayed timing of owners' actions on the behaviors of their dogs, Canis familiaris. Journal of Veterinary Behavior: Clinical Applications and Research, 4, 11-18.

Yeomans, L., Martin, L., \& Richter, T. (2019). Close companions: early evidence for dogs in northeast Jordan and the potential impact of new hunting methods. Journal of Anthropological Archaeology, 53, 161-173.

Yilmaz, O. (2017). Controversies of origin of domestic dogs - II - references of fossil dogs. Scholars Journal of Agriculture and Veterinary Sciences, 4(11), 476-483. 